\title{
Assessing Heavy Metal Contamination in Surface Sediments in an Urban River in the Philippines
}

\author{
Syrus Cesar Pacle Decena*, Michael Sanita Arguelles, Lydia Liporada Robel \\ Department of Environmental Management, Visayas State University-Alangalang, \\ Leyte 6517, Philippines
}

Received: 22 February 2017

Accepted: 21 June 2017

\begin{abstract}
The present study investigated heavy metal contaminations in Mangonbangon River, an urban river of Tacloban City, Philippines. Sediment samples were collected from 14 sampling sites and analyzed for total heavy metal content using acid digestion. Heavy metal concentrations ranged from 76.83-263.63 mg/Kg for Zn, 32.80-131.82 mg/Kg for Cr, 29.40-217.06 mg/Kg for Cu, 12.08-98.07 mg/Kg for $\mathrm{Ni}, 4.06-25.34 \mathrm{mg} / \mathrm{Kg}$ for $\mathrm{Co}$ and $12934.00-27332.00 \mathrm{mg} / \mathrm{Kg}$ for Fe. The average enrichment factor (EF) showed moderate and moderately severe enrichment for $\mathrm{Zn}$ and $\mathrm{Cu}$, respectively, minor enrichment for $\mathrm{Cr}, \mathrm{Ni}$, and $\mathrm{Co}$ and no enrichment for $\mathrm{Mn}$. The average contamination factor $(\mathrm{CF})$ of $\mathrm{Cu}$ and $\mathrm{Zn}$ indicated moderate contamination while $\mathrm{Cr}, \mathrm{Ni}, \mathrm{Mn}, \mathrm{Co}$ and $\mathrm{Fe}$ showed background concentrations. Results on geoaccumulation index (Igeo) showed that sediments were uncontaminated to moderately contaminated with $\mathrm{Cu}$ and $\mathrm{Zn}$ whereas Igeo for all other heavy metals indicated no contamination. For the overall pollution, pollution load index (PLI) showed that Mangonbangon River was unpolluted. Based on the comparison of heavy metals concentrations with the consensus-based sediment quality guidelines (SQGs), $\mathrm{Zn}, \mathrm{Cr}, \mathrm{Cu}$ and $\mathrm{Ni}$ were likely to result to the deleterious effect on bottom-dwelling organisms. Potential ecological risk index (RI) indicated low ecological risk in the sediments. Multivariate analyses revealed that $\mathrm{Cu}, \mathrm{Cr}, \mathrm{Ni}$ and $\mathrm{Fe}$ had common origin or geochemical behaviour and were associated with anthropogenic activities.
\end{abstract}

Keywords: heavy metals, heavy metal contamination, source apportionment, geoaccumulation index, Mangonbangon River

\section{Introduction}

Heavy metal contamination is a current and major environmental concern worldwide due to anthropogenic activities [1-2]. Heavy metal contamination in the environment has been occurring for centuries, and in the last decade it has increased rapidly due to technological

*e-mail: syrus_decenae2011@yahoo.com developments [3]. Anthropogenic activities that result in the discharge of heavy metals into the environment include industrial processes, mining, automobile emissions, agricultural, wastewater discharge, and urban runoff [4-5], while the natural sources of heavy metals may include weathering and dissolution of minerals, parent rocks, and soils [6-8].

Aquatic ecosystems like rivers are sinks of pollutants [9], probably because rivers as open systems are more vulnerable to contamination due to anthropogenic 
activities [10]. Ultimately, the river sediment serves as the primary sink for pollutants, including heavy metals [2]. Sediments are normally mixtures of several components, including different minerals and organic matter that can also play a significant role in the remobilization of contaminants in aquatic systems and in interactions between water and sediment [11]. The degree and range of heavy-metal pollution in sediment can be controlled by surface water transport and deposition by precipitation of solid particles from suspension [12]. Heavy metal contamination of sediments has received extensive attention as a result of their toxicity, hard degradation, and easy accumulation [13]. Since heavy metals are persistent in the aquatic ecosystem, increases in concentrations may result to their bioaccumulation in the tissues of various biota, and may affect the distribution and density of benthic organisms [9]. In addition, accumulated heavy metals in sediments are chemically altered by biological activity and converted into organic complexes, some of which may be more hazardous to animal and human life via the food chain [14].

Many cities in developing countries have been developed without adequate and proper planning. This has resulted in the indiscriminate discharge of wastes into aquatic ecosystems [15]. As a result of unplanned urbanization and industrialization in developing countries, rivers have been polluted with heavy metals [5, 16-17]. Therefore, this study was carried out to investigate heavy-metal contamination in the Mangonbangon River, an urban river of Tacloban City in Northeastern Leyte, Philippines. According to the best knowledge of the authors, no previous studies have been conducted regarding heavy metal contamination in the Mangonbangon. Hence, this research was intended to assess the extent of heavy metal contamination and to provide baseline information that could be used in monitoring pollution and as a guide for future developments. The objectives of the study were:

A) Determine the distributions of heavy metals ( $\mathrm{Zn}, \mathrm{Cr}$, $\mathrm{Cu}, \mathrm{Ni}, \mathrm{Mn}, \mathrm{Co}$, and $\mathrm{Fe}$ ) in the sediments.

B) Assess the contribution of anthropogenic activities on the level of heavy-metal contamination using indices such as enrichment factor (EF), contamination factor $(\mathrm{CF})$, geoaccumulation index $\left(I_{\text {geo }}\right)$, and pollution load index (PLI).

C) Assess potential risks associated with heavy metal toxicity using sediment quality guidelines (sqgs) and potential ecological risk index (RI).

D) Determine the source apportionment of heavy metals using multivariate analysis including Pearson's correlation, cluster analysis (CA), and principal component analysis (PCA).

\section{Materials and Methods}

\section{Study Area}

The study was conducted in Mangonbangon River located in Tacloban City in the northeastern portion of Leyte Island, Philippines (Fig. 1). The river is $4 \mathrm{~km}$ in length, which starts flowing from a wetland in the western side of the city before traversing the urban section. Finally, the river drains water to San Juanico Strait, which possibly pollutes the coastal area. Under the Corona Climate Classification System, the study area has a Type IV climate characterized with no dry season

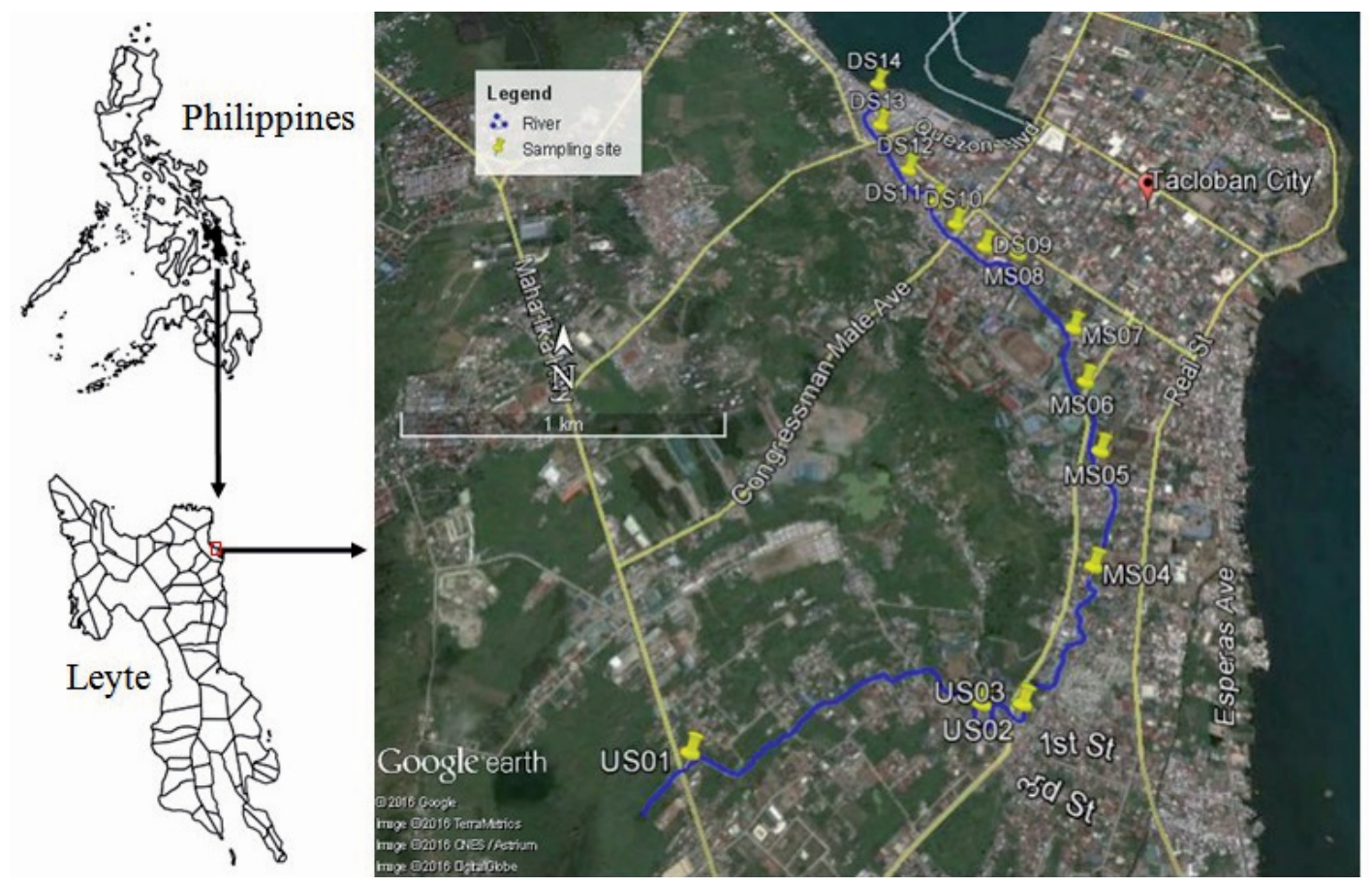

Fig. 1. Map of the study area and geographical location of sampling sites in Mangonbangon River. 
and more or less evenly distributed rainfall throughout the year. The warmest month is April, with an average temperature of $28.1^{\circ} \mathrm{C}$, and pronounced wetness occurs in the months of November, December, and January with rainfall of $279.0 \mathrm{~mm}, 305.3 \mathrm{~mm}$, and $281.17 \mathrm{~mm}$, respectively [18]. Soils of the study area are derived from alluvial deposits [19]. In this study, the river was subdivided into three sections, namely upstream (US01US03), midstream (MS04-MS08), and downstream (DS09-DS14).

\section{Sediment Collection and Preparation}

Sediment samples were collected from 14 sampling stations in the Mangonbangon on July 2016. One sample was collected at each sampling station. A $0-15 \mathrm{~cm}$ depth of sediment samples in the river were collected using a bucket auger. To reduce possible contamination, the sampler was decontaminated by washing with detergent and was rinsed with tap water and followed by rinsing distilled water before each use. Sediments were placed in a clean polyethylene zip-lock bag. Afterward, sediment samples were placed in a cooler with ice and kept at $4^{\circ} \mathrm{C}$ until analysis. Sampling sites were positioned with the use of handheld GPS (Garmin etrex).

The sediment samples were air-dried for 4 days. The large stones and other coarse debris were manually removed in the sediment samples and were homogenized and ground using a pestle and mortar. Ground samples were then sieved to pass through $63 \mu \mathrm{m}$ mesh size to obtain fine-powdered particles. Powdered sediment samples were placed in a clean polyethylene zip-lock bag and were kept refrigerated until further analysis.

\section{Sediment Analysis}

The acid digestion method was used to analyze total heavy metal contents of sediments. Sediment sample of $0.2 \mathrm{~g}$ were accurately weighed and placed in a dry and clean Teflon microwave digestion vessel, with $4 \mathrm{ml}$ of $\mathrm{H}_{2} \mathrm{SO}_{4}(96 \%)$ and $3 \mathrm{ml}$ of $\mathrm{H}_{3} \mathrm{PO}_{4}(85 \%)$ added to the vessel. The mixture was initially digested at $220^{\circ} \mathrm{C}$ for 10 minutes using microwave equipment (Model Milestone ETHOS). Afterward, the mixture was allowed to cool down, and finally $6 \mathrm{ml}$ of $\mathrm{HNO}_{3}(65 \%)$ and $12 \mathrm{ml}$ of $\mathrm{HBF}_{4}(40 \%)$ were added and digested again at the same temperature for 20 minutes. The resulting digest was filtered with Whatman No. 42 filter paper. Heavy-metal concentrations were measured using an air-acetylene flame atomic absorption spectrophotometer (AAS) (Shimadzu AA 6300).

\section{Quality Control}

To guarantee the quality of the analytical results, laboratory quality assurance and quality control methods were implemented such as pre-cleaning of laboratory materials with $10 \% \mathrm{HNO}_{3}$, use of standard operating procedures, analysis of blanks, calibration with the standard, and recovery of known additions. The percent recoveries of the known additions were $82.30 \%$ ( $\mathrm{Zn}), 101.20 \%(\mathrm{Cr}), 112.13 \%(\mathrm{Cu}), 97.09 \%(\mathrm{Ni}), 112.30 \%$ (Mn), 93.95\% (Co), and $114.77 \%(\mathrm{Fe})$. Each heavy metal was analyzed in three replicates and the results were presented as mean. The relative standard deviations (\%RSDs) of the replicates were $<5 \%$ for $\mathrm{Zn}, \mathrm{Cr}$, and $\mathrm{Fe}$; $<10 \%$ for $\mathrm{Cu}$; $<15 \%$ for $\mathrm{Ni}$ and $\mathrm{Mn}$; and $<20 \%$ for $\mathrm{Co}$.

\section{Assessment of Sediment Contamination}

\section{Enrichment Factor}

Calculating the enrichment factor (EF) is used to assess quantitatively the contribution of anthropogenic sources on the concentrations of heavy metals [20]. Enrichment factor is calculated as follows:

$$
\mathrm{EF}=\frac{\left[\frac{\mathrm{X}}{\mathrm{Fe}}\right] \text { sample }}{\left[\frac{\mathrm{X}}{\mathrm{Fe}}\right] \text { crust }}
$$

...where $[\mathrm{X} / \mathrm{Fe}]$ sample and $[\mathrm{X} / \mathrm{Fe}]$ crust refer to the ratios of concentrations of the target element and $\mathrm{Fe}$ in the sediments and continental crust, respectively. Since there are no values for reference metal of the study area, average shale [21] was used the same as in computing for contamination factor (CF), geoaccumulation index $\left(I_{g e o}\right)$, and pollution load index (PLI). An element is considered a reference element if it is of low occurrence variability and is present in the environment in trace amounts [22]. The reference elements that are used in calculating enrichment factor for heavy metals include $\mathrm{Cr}, \mathrm{Ca}, \mathrm{Fe}$, and $\mathrm{Al}$ [5, 22-25]. These reference elements are used in geochemical normalization of metal data because anthropogenic sources of these elements are small compared to natural sources [11]. The EF values were interpreted with the following categories, where: $\mathrm{EF}<1$ indicates no enrichment, $<3$ is minor enrichment, 3-5 is moderate enrichment, 5-10 is moderately severe enrichment, $10-25$ is severe enrichment, 25-50 is very severe enrichment, and $>50$ is extremely severe enrichment [26].

\section{Contamination Factor}

The contamination factor (CF) is an indicator of sediment contamination used in evaluating pollution in an aquatic environment by a given toxic substance [27]. Thus, to evaluate the level of heavy-metal contamination in sediments, $\mathrm{CF}$ is calculated with the following equation;

$$
\mathrm{CF}=\mathrm{C}_{\mathrm{m}} \text { Sample } / \mathrm{C}_{\mathrm{m}} \text { Background }
$$

...where $\mathrm{C}_{\mathrm{m}}$ Sample refers to the concentration of a given metal in sediment and $\mathrm{C}_{\mathrm{m}}$ Background refers to the value of a reference metal, which is the value of the metal in 
the average shale [21]. The CF values are categorized into 4, where: $\mathrm{CF}<1$ indicates low contamination, $1 \leq \mathrm{CF}<3$ is moderate contamination, $3 \leq \mathrm{CF}<6$ is considerable contamination, and $\mathrm{CF}>6$ is very high contamination [28].

\section{Geoaccumulation Index}

Geoaccumulation index $\left(I_{g e o}\right)$ was introduced by Muller [29] to assess the extent of contamination in bottom sediments by comparing the measured and pre-industrial concentrations of heavy metal in the earth's crust. It can also be applied in assessing contamination in soil [23]. The index is computed as follows:

$$
I_{\text {geo }}=\log _{2}\left(\mathrm{C}_{\mathrm{n}} / 1.5 \mathrm{~B}_{\mathrm{n}}\right)
$$

...where $\mathrm{C}_{\mathrm{n}}$ is the concentration of the target heavy metal in the sediment and $B_{n}$ is the geochemical background value. The constant 1.5 is a background correction factor introduced to reduce the effects of the lithogenic variations. The $I_{\text {geo }}$ consists of 7 classes ranging from practically uncontaminated to extremely polluted: Class 0 (practically uncontaminated): $I_{\text {geo }} \leq 0$; Class 1 (uncontaminated to moderately contaminated): $0<I_{\text {geo }}<1$; Class 2 (moderately contaminated): $1<I_{\text {geo }}<2$; Class 3 (moderately to heavily contaminated): $2<I_{\text {geo }}<3$; Class 4 (heavily contaminated): $3<I_{\text {geo }}<4$; Class 5 (heavily to extremely contaminated): $4<I_{\text {geo }}^{\text {geo }}<5$; and Class 6 (extremely contaminated): $5>I_{\text {geo }}[30]$.

\section{Pollution Load Index}

Pollution load index (PLI) was introduced to provide the public with some understanding of the quality of a component of the environment and it can indicate trends over time and area. In addition, the index also provides valuable information and advice for policy and decision makers on the pollution level of an aquatic ecosystem [31]. The PLI of a single site is obtained as the $n$th root of $n$ number of multiplied together contamination factor $(\mathrm{CF})$ values. The index is computed as follows:

$$
\mathrm{PLI}=\left(\mathrm{CF}_{1} \mathrm{xCF}_{2} \mathrm{xCF}_{3} \mathrm{x} \ldots \ldots \mathrm{CF}_{\mathrm{n}}\right)^{1 / \mathrm{n}}
$$

...where $n$ is the number of metals.

The PLI value of 0 indicates perfection, a value of one is baseline pollution, and lastly a value of $>1$ indicates increasing degradation of an aquatic ecosystem [31].

\section{Ecological Risk Assessment}

\section{Sediment Quality Guidelines}

The consensus-based sediment-quality guidelines (SQGs) were used in order to assess the possible risks that arise from heavy-metal contamination of surface sediments on bottom-dwelling organisms in an aquatic environment. This method has been widely used in assessing risk to aquatic organisms due to heavy-metal contamination in rivers [30, 32-34]. The assessment can be achieved through a comparison of measured heavy metal concentrations in sediment samples with the consensus-based threshold effect concentration (TEC) and probable effect concentration (PEC) values of the SQGs. There were 4 heavy metals ( $\mathrm{Zn}, \mathrm{Cr}, \mathrm{Cu}$, and $\mathrm{Ni}$ ) in this study that were compared with TEC and PEC values [35].

\section{Potential Ecological Risk Index}

The potential ecological risk index (RI) was originally developed by Håckanson [28], which is widely used in assessing ecological risk of heavy-metal pollution in sediments [36]. RI is computed as follows:

$$
\begin{gathered}
\mathrm{RI}=\Sigma E_{i} \\
E_{i}=T f_{i} \\
F_{i}=C_{i} / C_{b}
\end{gathered}
$$

...where RI refers to the sum of all risk factors in the sediment samples and $E_{i}$ is the monomial potential ecological risk factor for individual factors. $\mathrm{T}_{\mathrm{i}}$ refers to the metal toxic response factor (i.e., $\mathrm{Cu}=\mathrm{Ni}=\mathrm{Co}=5$, $\mathrm{Cr}=2$ and $\mathrm{Zn}=\mathrm{Mn}=1), F_{i}$ refers to the metal pollution factor, $C_{i}$ is the measured concentration of heavy metal in the sediment sample, and $C_{b}$ is the value of reference metal - the average shale [21]. The RI values were categorized as to the following: $\mathrm{RI}<150$ indicates low ecological risk, $150 \leq \mathrm{RI}<300$ indicates moderate ecological risk, $300 \leq \mathrm{RI}<600$ indicates considerable ecological risk, and $\mathrm{RI} \geq 600$ indicates very high ecological risk for the sediment [28].

\section{Statistical Analysis}

Multivariate statistical analyses provide important tolls for better understanding of the complex dynamics of pollutants in aquatic ecosystem [37]. Multivariate analyses including Pearson's correlation, cluster analysis (CA), and principal component analysis (PCA) were applied to define the source apportionment of heavy metals. Pearson correlation analysis was performed to determine the strength of interrelationship between target metals in the sediments. CA is helpful in explaining the spatial distribution of heavy metals in sediments [38]. CA is performed to classify elements of different sources on the basis of their similarities and to identify homogeneous variables having similar properties [24]. In this research, hierarchical agglomerative CA was performed using the nearest neighbour method and Pearson correlation as a measure of similarity. Moreover, to further assess the origin of 
Table 1. Sampling sites, geographic coordinates and description of sampling sites.

\begin{tabular}{|c|c|c|c|}
\hline \multirow{2}{*}{ Sampling Site } & \multicolumn{2}{|c|}{ Geographic Coordinates } & \multirow{2}{*}{ Description and Activities } \\
\hline & Latitude & Longitude & \\
\hline \multicolumn{4}{|r|}{ Upstream } \\
\hline US01 & $11^{\circ} 13^{\prime} 40.4^{\prime \prime}$ & $124^{\circ} 59^{\prime} 24.3^{\prime \prime}$ & Gas/fuel station, vehicle traffic, commercial and sand and gravel aggregates \\
\hline US02 & $11^{\circ} 13^{\prime} 43.9^{\prime \prime}$ & $124^{\circ} 59^{\prime} 50.7^{\prime \prime}$ & Residential, vehicle traffic \\
\hline US03 & $11^{\circ} 13^{\prime} 44.1^{\prime \prime}$ & $124^{\circ} 59^{\prime} 54.3^{\prime \prime}$ & Vehicle traffic, residential, sewerage and commercial \\
\hline \multicolumn{4}{|r|}{ Midstream } \\
\hline MS04 & $11^{\circ} 13^{\prime} 59.4^{\prime \prime}$ & $125^{\circ} 00^{\prime} 03.7^{\prime \prime}$ & Vehicle traffic, residential and autoshops \\
\hline MS05 & $11^{\circ} 14^{\prime} 07.8^{\prime \prime}$ & $125^{\circ} 00^{\prime} 04.1^{\prime \prime}$ & Sewerage, residential and vehicle traffic \\
\hline MS06 & $11^{\circ} 14^{\prime} 15.3^{\prime \prime}$ & $125^{\circ} 00^{\prime} 03.5^{\prime \prime}$ & Vehicle traffic, sewerage, car washing bay and metal works and fabrication \\
\hline MS07 & $11^{\circ} 14^{\prime} 21.4^{\prime \prime}$ & $125^{\circ} 00^{\prime} 02.9^{\prime \prime}$ & Residential, vehicle traffic and sewerage \\
\hline MS08 & $11^{\circ} 14^{\prime} 30.7^{\prime \prime}$ & $124^{\circ} 59^{\prime} 56.3^{\prime \prime}$ & Hospital, commercial, residential and vehicle parking area \\
\hline \multicolumn{4}{|r|}{ Downstream } \\
\hline DS09 & $11^{\circ} 14^{\prime} 31.0 "$ & $124^{\circ} 59^{\prime} 53.8^{\prime \prime}$ & Residential, commercial, vehicle parking area and sewerage \\
\hline DS10 & $11^{\circ} 14^{\prime} 33.9^{\prime \prime}$ & $124^{\circ} 59^{\prime} 50.9^{\prime}$ & Residential, vehicle traffic, commercial, car washing bay and gas/fuel station \\
\hline DS11 & $11^{\circ} 14^{\prime} 37.5^{\prime \prime}$ & $124^{\circ} 59^{\prime} 48.7^{\prime \prime}$ & $\begin{array}{l}\text { Motor/autoshops, sewerage, residential and slum, carpentry works, vehicular } \\
\text { traffic, and commercial }\end{array}$ \\
\hline DS12 & $11^{\circ} 14^{\prime} 40.0^{\prime \prime}$ & $124^{\circ} 59^{\prime} 47.8^{\prime \prime}$ & Sewerage, residential and slum and solid waste dumping \\
\hline DS13 & $11^{\circ} 14^{\prime} 47.1^{\prime \prime}$ & $124^{\circ} 59^{\prime} 42.6^{\prime \prime}$ & $\begin{array}{l}\text { Vehicle traffic, residential and slum, commercial, sewerage, motor/autoshops } \\
\text { and gas/fuel station }\end{array}$ \\
\hline DS14 & $11^{\circ} 14^{\prime} 53.4^{\prime \prime}$ & $124^{\circ} 59^{\prime} 42.5^{\prime \prime}$ & Residential and slum, sewerage, vehicle traffic and solid waste dumping \\
\hline
\end{tabular}

heavy metals in the sediments we applied PCA [39]. PCA was performed using varimax normalized rotation on the dataset. As a requirement before the PCA, KaiserMeyer-Olkin (KMO) and Bartlett's Test of Sphericity were introduced to evaluate its validity with $\mathrm{a}>0.5$ of KMO (0.548) and significant Bartlett's test $(p=0.001)$.

All the metal concentrations were normally distributed when tested for normal distribution using the Kolmogorov-Smirnov test. The computations and statistical analysis were carried out using Microsoft Office Excel 2007 and SPSS 20 for Windows.

\section{Results and Discussion}

\section{Heavy Metal Distribution}

The heavy metal concentrations of sediments in the Mangonbangon River are presented in Table 2. The concentration of $\mathrm{Zn}$ in the sediments varied from 76.83 to $263.63 \mathrm{mg} / \mathrm{Kg}$ with an average of 213.71 $\mathrm{mg} / \mathrm{Kg}$. Studies suggested that $\mathrm{Zn}$ has high mobility [13, 40-41] and the presence of the element in dissolved species potentially increases its bioavailability in an aquatic environment [42]. $\mathrm{Zn}$ is easily adsorbed and scavenged by the hydroxide and oxides [43]. The elevated concentration of $\mathrm{Zn}$ in the sediments could be attributed to vehicular emissions and commercial and industrial discharges [24, 44]. The $\mathrm{Cr}$ concentration ranged from 32.80 to $131.82 \mathrm{mg} / \mathrm{Kg}$ with an average of $89.45 \mathrm{mg} / \mathrm{Kg}$. The heavy metal $\mathrm{Cr}$ is considered to be a low mobility element, especially under moderately oxidizing and reducing conditions and nearly neutral $\mathrm{pH}$. This heavy metal and its compound are primarily used in manufacturing steel and other alloys, chrome plating, and pigment production [11]. Total $\mathrm{Cu}$ content of the sediment ranged from 29.40 to $217.06 \mathrm{mg} / \mathrm{Kg}$ with an average of $116.36 \mathrm{mg} / \mathrm{Kg}$. This element is crucial for the proper growth of the plants because it is a component of various enzymes and proteins [23]. $\mathrm{Cu}$ is widely use in electrical wiring, roofing, and production of alloys, pigments, cooking utensils, and piping [17]. Further, contamination of the environment with $\mathrm{Cu}$ is being linked with the application of agrochemicals [15]. The Ni concentration in the sediment ranged from 12.08 to $98.07 \mathrm{mg} / \mathrm{Kg}$ with a mean of $61.14 \mathrm{mg} / \mathrm{Kg}$. $\mathrm{Ni}$ is usually present in the organically bound form in soil, which under acidic and neutral conditions increases its mobility and bioavailability [23]. The identified major anthropogenic sources of $\mathrm{Ni}$ are nickel wood, fuel combustion, agricultural wastes, and domestic sludge [8]. Concentration of Mn ranged from 170.68 to $405.51 \mathrm{mg} / \mathrm{Kg}$ with an average of $261.97 \mathrm{mg} / \mathrm{Kg}$. Mn has a totally different behavior compared to other heavy metals and seems to be controlled by the precipitation of $\mathrm{MnO}_{2}$ in oxic surface sediments [45]. The contamination 
Table 2. Heavy metal concentrations $(\mathrm{mg} / \mathrm{Kg}$ ) in surface sediments in Mangonbangon River.

\begin{tabular}{|c|c|c|c|c|c|c|c|}
\hline Sampling Site & $\mathrm{Zn}$ & $\mathrm{Cr}$ & $\mathrm{Cu}$ & $\mathrm{Ni}$ & $\mathrm{Mn}$ & $\mathrm{Co}$ & $\mathrm{Fe}$ \\
\hline US01 & 76.83 & 86.72 & 83.56 & 37.69 & 356.52 & 13.50 & 24589.00 \\
\hline US02 & 178.97 & 32.80 & 29.40 & 12.08 & 315.83 & 15.90 & 12934.00 \\
\hline US03 & 179.12 & 131.82 & 146.64 & 62.79 & 405.51 & 8.26 & 27332.00 \\
\hline MS04 & 192.59 & 127.53 & 172.75 & 62.96 & 275.09 & 11.88 & 23853.00 \\
\hline MS05 & 263.63 & 88.37 & 101.91 & 66.80 & 239.73 & 5.57 & 18590.67 \\
\hline MS06 & 200.64 & 67.29 & 113.02 & 56.67 & 265.95 & 23.21 & 20334.33 \\
\hline MS07 & 218.11 & 74.10 & 124.89 & 53.34 & 320.87 & 19.68 & 25806.00 \\
\hline MS08 & 234.65 & 95.04 & 100.47 & 64.43 & 270.22 & 18.98 & 21407.67 \\
\hline DS09 & 238.09 & 126.64 & 125.62 & 97.01 & 187.37 & 17.19 & 23534.33 \\
\hline DS10 & 240.04 & 120.66 & 109.67 & 79.28 & 220.55 & 19.30 & 19542.67 \\
\hline DS11 & 244.75 & 110.33 & 217.06 & 98.07 & 194.41 & 25.34 & 26621.67 \\
\hline DS12 & 235.91 & 46.89 & 102.28 & 66.87 & 189.20 & 10.66 & 20015.33 \\
\hline DS13 & 246.41 & 54.62 & 123.35 & 51.82 & 170.68 & 4.06 & 26564.33 \\
\hline DS14 & 242.13 & 89.42 & 78.42 & 46.18 & 255.59 & 20.84 & 16961.00 \\
\hline Minimum & 76.83 & 32.80 & 29.40 & 12.08 & 170.68 & 4.06 & 12934.00 \\
\hline Maximum & 263.63 & 131.82 & 217.06 & 98.07 & 405.51 & 25.34 & 27332.00 \\
\hline Mean & 213.71 & 89.45 & 116.36 & 61.14 & 261.97 & 15.31 & 22006.14 \\
\hline Average shale [21] & 95.00 & 90.00 & 45.00 & 68.00 & 850.00 & 19.00 & 46000.00 \\
\hline
\end{tabular}

with Mn could result from atmospheric deposition and release from organic matter [46]. The Co concentration in the sediment ranged from 4.06 to $25.34 \mathrm{mg} / \mathrm{Kg}$ with an average of $15.31 \mathrm{mg} / \mathrm{Kg}$. In this study, Fe appeared to have higher concentration than any other heavy metal in Mangonbangon surface sediments. The concentrations of $\mathrm{Fe}$ in sediments ranged from $12,934.00$ to $27,332.00 \mathrm{mg} / \mathrm{Kg}$, with an average of $22,006.14 \mathrm{mg} / \mathrm{Kg}$. Besides weathering, erosion, and other natural sources, the abundance of $\mathrm{Fe}$ in a river ecosystem can be attributed to large-scale human activities such as urban-industrial releases, municipal solid waste, construction and demolition waste, and agricultural activities [17]. The overall trend of heavy metal concentrations in the river was $\mathrm{Fe}>\mathrm{Mn}>\mathrm{Zn}>$ $\mathrm{Cu}>\mathrm{Cr}>\mathrm{Ni}>\mathrm{Co}$. The trend was almost similar as reported from the Ganga River in India [17] and the Huaihe River in China [32]. Highest concentrations of metals, including $\mathrm{Fe}, \mathrm{Mn}$, and $\mathrm{Cr}$, were found upstream, particularly in sampling site US03. These heavy metals except Fe showed a decreasing trend toward the downstream. The highest concentrations of $\mathrm{Cu}, \mathrm{Ni}$, and Co were found in sampling site DS11 in the downstream and $\mathrm{Zn}$ in sampling site MS05 in the midstream.

The mean concentrations of heavy metals were compared to the average shale [21] since there were no background values for the study area. The mean concentrations of $\mathrm{Zn}$ and $\mathrm{Cu}$ in the studied river exceeded the average shale. Mean $\mathrm{Cr}$ concentration was still comparable with the average shale. On the other hand, the majority, such as $\mathrm{Ni}, \mathrm{Mn}, \mathrm{Co}$, and Fe remained below the average shale, which indicates less pollution with respect to these heavy metals (Table 2).

\section{Comparisons with Previous Studies}

The mean concentrations of heavy metals were compared with previous studies on some rivers worldwide, including the Ganga [17] and the Gomti in India [47], the Korotoa in Bangladesh [48], the Langat in Malaysia [49], the Huaihe [32] and Jialu in China [33], the Shur in Iran [50], and the Tigris in Turkey [30] (Table 3). The concentrations of $\mathrm{Zn}$ and $\mathrm{Cu}$ in large rivers, including the Tigris and Shur - where pollution is associated with major metal industry exceeding the concentrations in the present study. Likewise, $\mathrm{Cr}$ and $\mathrm{Ni}$ concentrations did not exceed the values in the Tigris and Korotoa rivers, but higher compared to the rest of rivers listed. The level of Mn determined in the Ganga urban river and Huaihe were comparatively higher against the value in this study. Similarly, mean Fe concentrations reported in the Ganga, Langat, Huaihe, and Shur rivers appeared to be higher.

\section{Assessing Sediment Contamination}

In this study, average shale [21] was used as a background value for heavy metals $(\mathrm{Zn}, \mathrm{Cr}, \mathrm{Cu}, \mathrm{Ni}, \mathrm{Mn}$, 


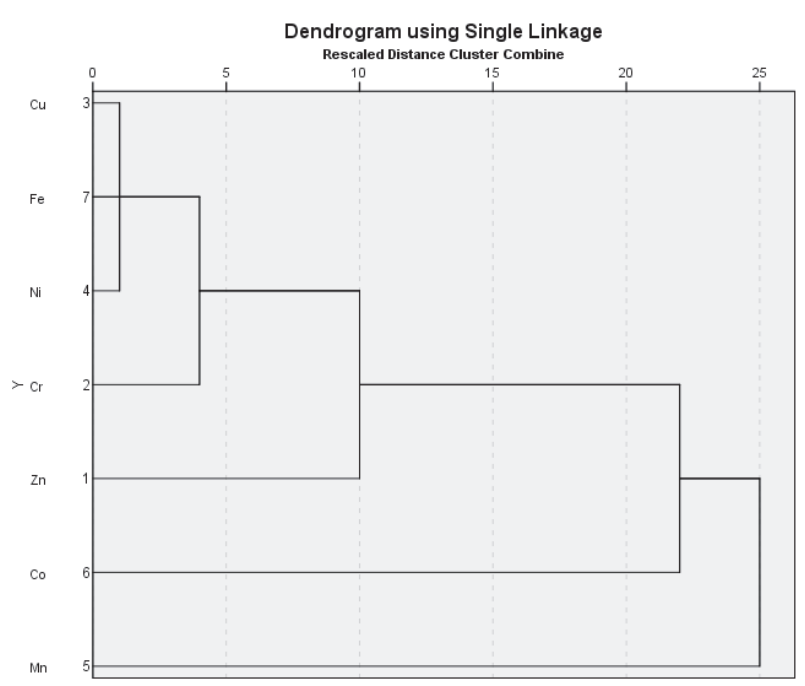

Fig. 2. Hierarchical dendrogram for heavy metals in sediments of the Mangonbangon River using the nearest neighbour method and Pearson correlation with $\mathrm{z}$ standardization.

$\mathrm{Co}$, and $\mathrm{Fe}$ ) since there were no existing background values for these heavy metals in the study area. In evaluating enrichment factor (EF), the widely used $\mathrm{Fe}$ $[11,17,24,27]$ as a reference element was used in this study. The heavy metals EF values followed the order $\mathrm{Cu}$ $>\mathrm{Zn}>\mathrm{Cr}>\mathrm{Ni}>\mathrm{Co}>\mathrm{Mn}$. The EF values of Mn were about normal, indicating background concentrations and hence posing no significant pollution in the river. Average EF values for $\mathrm{Cr}, \mathrm{Ni}$, and $\mathrm{Co}$ were $<3$, which suggested minor enrichment of these heavy metals in the sediments. The mean $\mathrm{EF}$ values for $\mathrm{Zn}(>3)$ and $\mathrm{Cu}(>5)$ indicated moderate and moderately severe enrichment, respectively, and may pose concern over the pollution of these heavy metals in the Mangonbangon River. The highest EF value for $\mathrm{Zn}$ was found in the downstream site (DS14) with EF value of $>5$, suggesting moderately severe enrichment. The high concentration of $\mathrm{Zn}$ in the downstream could be related from sources such as domestic sewage and influx from the upstream. The studied heavy metal that exhibited the highest EF value was $\mathrm{Cu}$ in the downstream site (DS11), with EF value also of $>5$, indicating moderately severe enrichment (Table 4). The enrichment of $\mathrm{Cu}$ could be attributed from pollution sources such as waste discharge from sewers, motor/auto shops, and urban runoff. In addition, correlation analysis showed that $\mathrm{Cu}$ was strongly correlated with $\mathrm{Cr}, \mathrm{Ni}$, and $\mathrm{Fe}$ (Table 9), and the release of these heavy metals may also enhance the enrichment of $\mathrm{Cu}$ in surface sediments. It is presumed that high EF values indicate an anthropogenic source of heavy metals - mainly from activities such as industrialization, urbanization, deposition of industrial wastes, and others. The bioavailability and toxicity of heavy metals in sediments are dependent upon on their concentrations and chemical form [51]. Thus, heavy metals in sediment samples with high EF values, along with higher labile fractions in sediments, have the potential for mobility and bioavailability in aquatic ecosystems [48].

The highest $\mathrm{CFs}$ for $\mathrm{Cr}$ (1.46), Mn (0.48), and Fe (0.59) were found in an upstream site (US03) in which the possible sources of these heavy metals were domestic, residential, and waste discharge from sewers (Table 5). The high $\mathrm{CF}$ value of $\mathrm{Zn}$ was found in the midstream (MS05), whereas the highest CF values for $\mathrm{Cu}$ (4.82), Ni (1.44), and Co (1.33) were found in the downstream site (DS11), which could be due to waste discharge from sewers, residential, domestic, and commercial establishments. The average CF values for $\mathrm{Cu}$ and $\mathrm{Zn}$ were 2.59 and 2.25, respectively, indicating that the Mangonbangon was moderately contaminated with respect to these heavy metals. In contrast, the average $\mathrm{CF}$ values for $\mathrm{Cr}, \mathrm{Ni}, \mathrm{Mn}, \mathrm{Co}$, and $\mathrm{Fe}$ were below one, which suggested lithogenic sources. Based on the results, average $\mathrm{CF}$ values for heavy metals decreased in the following order: $\mathrm{Cu}>\mathrm{Zn}>\mathrm{Cr}>\mathrm{Ni}>$ $\mathrm{Co}>\mathrm{Fe}>\mathrm{Mn}$.

Table 3. Comparison of heavy metal concentrations in sediments of Mangonbangon River with other world rivers.

\begin{tabular}{|c|c|c|c|c|c|c|c|c|c|}
\hline Location & Unit & $\mathrm{Zn}$ & $\mathrm{Cr}$ & $\mathrm{Cu}$ & $\mathrm{Ni}$ & $\mathrm{Mn}$ & $\mathrm{Co}$ & $\mathrm{Fe}$ & References \\
\hline $\begin{array}{c}\text { Mangonbangon River (urban } \\
\text { river), Philippines }\end{array}$ & $\mathrm{mg} / \mathrm{Kg}$ & 213.71 & 89.45 & 116.36 & 61.14 & 261.97 & 15.31 & 22006.14 & This study \\
\hline $\begin{array}{c}\text { Ganga River (urban river), } \\
\text { India }\end{array}$ & $\mu \mathrm{g} / \mathrm{g}$ & 67.76 & 69.94 & 29.75 & 26.70 & 372.04 & - & 31988.60 & {$[17]$} \\
\hline $\begin{array}{c}\text { Gomti River (urban river), } \\
\text { India }\end{array}$ & $\mathrm{mg} / \mathrm{Kg}$ & 76.34 & 16.19 & 23.23 & 23.92 & - & - & - & {$[47]$} \\
\hline $\begin{array}{c}\text { Korotoa River (urban river), } \\
\text { Bangladesh }\end{array}$ & $\mathrm{mg} / \mathrm{Kg}$ & - & 109 & 76 & 95 & - & - & - & {$[48]$} \\
\hline $\begin{array}{c}\text { Langat River, Malaysia } \\
\text { Huaihe River, China }\end{array}$ & $\mu \mathrm{mg} / \mathrm{g}$ & - & 21.03 & - & 7.84 & - & - & 28300.00 & {$[49]$} \\
\hline Jialu River, China & $\mathrm{mg} / \mathrm{Kg}$ & 107.58 & 60.80 & 39.22 & 42.44 & - & - & - & {$[33]$} \\
\hline Shur River, Iran & $\mathrm{ppm}$ & 522 & - & 9,174 & - & - & - & 26000.00 & {$[50]$} \\
\hline Tigris River, Turkey & $\mathrm{mg} / \mathrm{Kg}$ & 509.84 & 135.81 & 1257.76 & 284.00 & - & - & - & {$[30]$} \\
\hline
\end{tabular}


Table 4. Enrichment factors (EF) of heavy metals in surface sediments in all sampling stations in Mangonbangon River.

\begin{tabular}{|c|c|c|c|c|c|c|}
\hline $\begin{array}{c}\text { Sampling } \\
\text { Site }\end{array}$ & $\mathrm{Zn}$ & $\mathrm{Cr}$ & $\mathrm{Cu}$ & $\mathrm{Ni}$ & $\mathrm{Mn}$ & $\mathrm{Co}$ \\
\hline US01 & 1.51 & 1.80 & 3.47 & 1.04 & 0.78 & 1.33 \\
\hline US02 & 6.70 & 1.30 & 2.32 & 0.63 & 1.32 & 2.98 \\
\hline US03 & 3.17 & 2.47 & 5.48 & 1.55 & 0.80 & 0.73 \\
\hline MS04 & 3.91 & 2.73 & 7.40 & 1.79 & 0.62 & 1.21 \\
\hline MS05 & 6.87 & 2.43 & 5.60 & 2.43 & 0.70 & 0.73 \\
\hline MS06 & 4.78 & 1.69 & 5.68 & 1.89 & 0.71 & 2.76 \\
\hline MS07 & 4.09 & 1.47 & 4.95 & 1.40 & 0.67 & 1.85 \\
\hline MS08 & 5.31 & 2.27 & 4.80 & 2.04 & 0.68 & 2.15 \\
\hline DS09 & 4.90 & 2.75 & 5.46 & 2.79 & 0.43 & 1.77 \\
\hline DS10 & 5.95 & 3.16 & 5.74 & 2.74 & 0.61 & 2.39 \\
\hline DS11 & 4.45 & 2.12 & 8.33 & 2.49 & 0.40 & 2.30 \\
\hline DS12 & 5.71 & 1.20 & 5.22 & 2.26 & 0.51 & 1.29 \\
\hline DS13 & 4.49 & 1.05 & 4.75 & 1.32 & 0.35 & 0.37 \\
\hline DS14 & 6.91 & 2.69 & 4.73 & 1.84 & 0.82 & 2.97 \\
\hline $\begin{array}{c}\text { Mini- } \\
\text { mum }\end{array}$ & 1.51 & 1.05 & 2.32 & 0.63 & 0.35 & 0.37 \\
\hline $\begin{array}{c}\text { Maxi- } \\
\text { mum }\end{array}$ & 6.91 & 3.16 & 8.33 & 2.79 & 1.32 & 2.98 \\
\hline Mean & 4.91 & 2.08 & 5.28 & 1.87 & 0.67 & 1.77 \\
\hline
\end{tabular}

The results on the calculation of geoaccumulation index $\left(I_{\text {geo }}\right)$ based on average shale [21] are presented in Table 6, where $I_{\text {geo }}$ values varied from -0.89 to 0.89 for $\mathrm{Zn},-2.04$ to -0.03 for $\mathrm{Cr},-1.20$ to 1.69 for $\mathrm{Cu},-3.08$ to -0.06 for $\mathrm{Ni},-2.90$ to -1.65 for $\mathrm{Mn},-2.81$ to -0.17 for $\mathrm{Co}$, and -2.42 to -1.34 for Fe. The $I_{g e o}$ values for $\mathrm{Cr}, \mathrm{Ni}, \mathrm{Mn}$, $\mathrm{Co}$, and $\mathrm{Fe}$ in all sampling sites fell under class 0 , which suggested that the sediments were uncontaminated with these heavy metals. The $I_{\text {geo }}$ values for $\mathrm{Cu}$ fell under classes 1 and 2, which suggested that the sediments were uncontaminated to moderately contaminated and moderately contaminated, respectively, except in sampling site US02, which fell to class 0 (indicating no contamination). The high $I_{\text {geo }}$ value for $\mathrm{Cu}$ could be the result of increasing pollution due to waste discharge from sewers, residential, motor/auto shops, metal fabrications, and commercial. The $I_{g e o}$ values of $\mathrm{Zn}$ for all sampling sites fell under class 1 , which indicated uncontaminated to moderately contaminated except in sampling site US01, which fell to class 0 (indicating no contamination). The $I_{g e o}$ values indicated pollution for $\mathrm{Cu}$ and $\mathrm{Zn}$ in the surface sediments due to anthropogenic activities. This was supported by the results of the PCA, whereby the presence of $\mathrm{Cu}$ and $\mathrm{Zn}$ in the first and second components could suggest anthropogenic sources of these heavy metals (Fig. 3).

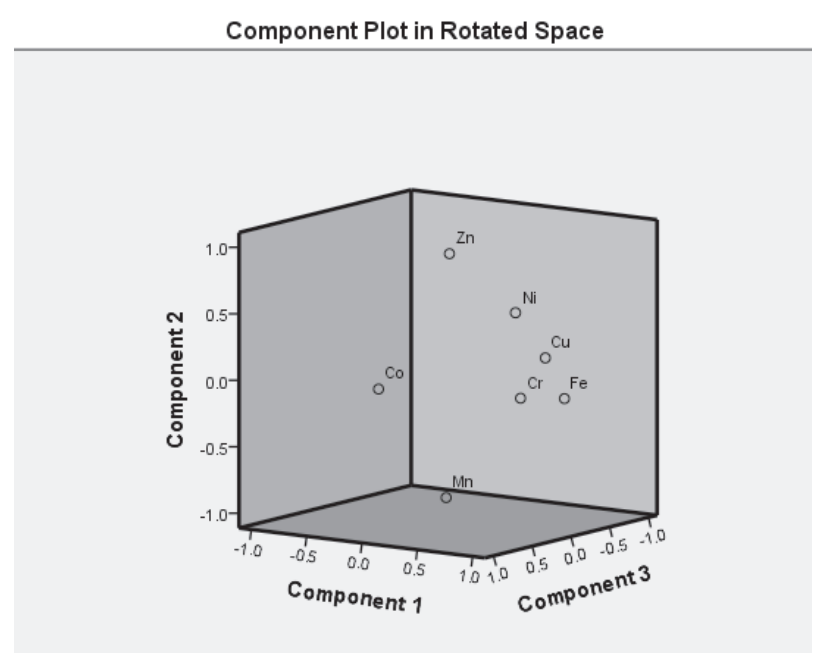

Fig. 3. Plot of loading of three principal components in PCA results.

The results on the analysis on pollution load index (PLI) are shown in Table 6. The PLI values ranged from 0.49 to 1.21 and with an average of 0.89 , which suggested no pollution in the Mangonbangon. However, sampling sites MS04 (midstream), DS09, DS10, and DS11 (downstream) had PLI values of 1.01, 1.05, 1.01, and 1.21, respectively, which suggested that sediments at these sections of the river were polluted. Based on the PLI criteria [31], these results indicated progressive deterioration of the aquatic ecosystem.

\section{Ecological Risk Assessment Results}

\section{Sediment Quality Guidelines}

In order to assess the associated risks of heavy metal toxicity on bottom-dwelling organisms, concentrations of heavy metals in this study were compared with consensus-based threshold effect concentration (TEC) and probable effect concentration (PEC) values of the SQGs [35]. As depicted in Table 7, the percentage of samples with $\mathrm{Zn}, \mathrm{Cr}, \mathrm{Cu}$, and $\mathrm{Ni}$ concentrations that did not exceed the TEC value was only $7.10 \%$ for each heavy metal. In other words, the majority $(92.9 \%)$ of the sediment samples had concentrations of heavy metals exceeding TEC. The percentage of samples with $\mathrm{Cr}$, $\mathrm{Cu}$, and $\mathrm{Ni}$ concentrations exceeding PEC value were $28.60 \%, 14.30 \%$, and $78.60 \%$, respectively, while $0 \%$ of the samples had exceeded PEC value for $\mathrm{Zn}$. The heavy metals that exceeded PEC value the least and most were $\mathrm{Cu}$ and $\mathrm{Ni}$, respectively. The concentrations of heavy metals in sediments below TEC value were unlikely to result in the deleterious effect on bottomdwelling organisms, while the exceedance of heavy metal concentrations in sediments with PEC values of SQGs were likely to result to the deleterious effect on bottom-dwelling organisms that were expected to occur frequently [30]. 
Table 5. The contamination factors (CF) of heavy metals in surface sediments in all sampling stations in Mangonbangon River.

\begin{tabular}{|c|c|c|c|c|c|c|c|}
\hline Sampling Site & $\mathrm{Zn}$ & $\mathrm{Cr}$ & $\mathrm{Cu}$ & $\mathrm{Ni}$ & $\mathrm{Mn}$ & $\mathrm{Co}$ & $\mathrm{Fe}$ \\
\hline US01 & 0.81 & 0.96 & 1.86 & 0.55 & 0.42 & 0.71 & 0.53 \\
\hline US02 & 1.88 & 0.36 & 0.65 & 0.18 & 0.37 & 0.84 & 0.28 \\
\hline US03 & 1.89 & 1.46 & 3.26 & 0.92 & 0.48 & 0.43 & 0.59 \\
\hline MS04 & 2.03 & 1.42 & 3.84 & 0.93 & 0.32 & 0.63 & 0.52 \\
\hline MS05 & 2.78 & 0.98 & 2.26 & 0.98 & 0.28 & 0.29 & 0.40 \\
\hline MS06 & 2.11 & 0.75 & 2.51 & 0.83 & 0.31 & 1.22 & 0.44 \\
\hline MS07 & 2.30 & 0.82 & 2.78 & 0.78 & 0.38 & 1.04 & 0.56 \\
\hline MS08 & 2.47 & 1.06 & 2.23 & 0.95 & 0.32 & 1.00 & 0.47 \\
\hline DS09 & 2.51 & 1.41 & 2.79 & 1.43 & 0.22 & 0.90 & 0.51 \\
\hline DS10 & 2.53 & 1.34 & 2.44 & 1.17 & 0.26 & 1.02 & 0.42 \\
\hline DS11 & 2.58 & 1.23 & 4.82 & 1.44 & 0.23 & 1.33 & 0.58 \\
\hline DS12 & 2.48 & 0.52 & 2.27 & 0.98 & 0.22 & 0.56 & 0.44 \\
\hline DS13 & 2.59 & 0.61 & 2.74 & 0.76 & 0.20 & 0.21 & 0.58 \\
\hline DS14 & 2.55 & 0.99 & 1.74 & 0.68 & 0.30 & 1.10 & 0.37 \\
\hline Minimum & 0.81 & 0.36 & 0.65 & 0.18 & 0.20 & 0.21 & 0.28 \\
\hline Maximum & 2.78 & 1.46 & 4.82 & 1.44 & 0.48 & 1.33 & 0.59 \\
\hline Mean & 2.25 & 0.99 & 2.59 & 0.90 & 0.31 & 0.81 & 0.48 \\
\hline
\end{tabular}

Table 6. Geoaccumulation indices (Igeo) and pollution load indices (PLI) of heavy metals in surface sediments in all sampling stations in Mangonbangon River.

\begin{tabular}{|c|c|c|c|c|c|c|c|c|}
\hline Sampling Site & $\mathrm{Zn}$ & $\mathrm{Cr}$ & $\mathrm{Cu}$ & $\mathrm{Ni}$ & $\mathrm{Mn}$ & $\mathrm{Co}$ & $\mathrm{Fe}$ & $\mathrm{PLI}$ \\
\hline US01 & -0.89 & -0.64 & 0.31 & -1.44 & -1.84 & -1.08 & -1.49 & 0.74 \\
\hline US02 & 0.33 & -2.04 & -1.20 & -3.08 & -2.01 & -0.84 & -2.42 & 0.49 \\
\hline US03 & 0.33 & -0.03 & 1.12 & -0.70 & -1.65 & -1.79 & -1.34 & 1.00 \\
\hline MS04 & 0.43 & -0.08 & 1.36 & -0.70 & -2.21 & -1.26 & -1.53 & 1.01 \\
\hline MS05 & 0.89 & -0.61 & 0.59 & -0.61 & -2.41 & -2.36 & -1.89 & 0.79 \\
\hline MS06 & 0.49 & -1.00 & 0.74 & -0.85 & -2.26 & -0.30 & -1.76 & 0.92 \\
\hline MS07 & 0.61 & -0.87 & 0.89 & -0.94 & -1.99 & -0.53 & -1.42 & 0.99 \\
\hline MS08 & 0.72 & -0.51 & 0.57 & -0.66 & -2.24 & -0.59 & -1.69 & 0.97 \\
\hline DS09 & 0.74 & -0.09 & 0.90 & -0.07 & -2.77 & -0.73 & -1.55 & 1.05 \\
\hline DS10 & 0.75 & -0.16 & 0.70 & -0.36 & -2.53 & -0.56 & -1.82 & 1.01 \\
\hline DS11 & 0.78 & -0.29 & 1.69 & -0.06 & -2.71 & -0.17 & -1.37 & 1.21 \\
\hline DS12 & 0.73 & -1.53 & 0.60 & -0.61 & -2.75 & -1.42 & -1.79 & 0.77 \\
\hline DS13 & 0.79 & -1.31 & 0.87 & -0.98 & -2.90 & -2.81 & -1.38 & 0.70 \\
\hline DS14 & 0.76 & -0.59 & 0.22 & -1.14 & -2.32 & -0.45 & -2.02 & 0.87 \\
\hline Minimum & -0.89 & -2.04 & -1.20 & -3.08 & -2.90 & -2.81 & -2.42 & 0.49 \\
\hline Maximum & 0.89 & -0.03 & 1.69 & -0.06 & -1.65 & -0.17 & -1.34 & 1.21 \\
\hline Mean & 0.53 & -0.70 & 0.67 & -0.87 & -2.33 & -1.06 & -1.68 & 0.89 \\
\hline
\end{tabular}


Table 7. Comparison of consensus-based sediment-quality guidelines (SQGs) with the heavy metal concentrations in sediments in all sampling stations in Mangonbangon River.

\begin{tabular}{|c|c|c|c|c|c|}
\hline & & $\mathrm{Zn}$ & $\mathrm{Cr}$ & $\mathrm{Cu}$ & $\mathrm{Ni}$ \\
\hline \multirow{3}{*}{ SQGs } & TEC & 121 & 43.4 & 31.6 & 22.7 \\
\cline { 2 - 6 } & PEC & 459 & 111 & 149 & 48.6 \\
\hline \multirow{4}{*}{$\begin{array}{c}\text { Values } \\
\text { in the } \\
\text { studied } \\
\text { river }\end{array}$} & Minimum & 76.83 & 32.80 & 29.40 & 12.08 \\
\cline { 2 - 6 } & \begin{tabular}{c} 
Maximum \\
\cline { 2 - 6 }
\end{tabular} & 263.63 & 131.82 & 217.06 & 98.07 \\
\cline { 2 - 6 } & Mean & 213.71 & 89.45 & 116.36 & 61.14 \\
\cline { 2 - 6 } & $\begin{array}{c}\text { \% of samples } \\
\text { > PEC }\end{array}$ & 7.10 & 7.10 & 7.10 & 7.10 \\
\hline
\end{tabular}

\section{Potential Ecological Risk Index (RI)}

The $E_{i}$ and $R I$ of sediments in all Mangonbangon sampling sites were calculated in Table 8 . The $E_{i}$ for each heavy metal declined in the following order: $\mathrm{Cu}>\mathrm{Ni}>\mathrm{Co}>\mathrm{Zn}>\mathrm{Cr}>\mathrm{Mn}$. Among the heavy metals studied, $\mathrm{Cu}, \mathrm{Ni}$, and $\mathrm{Co}$ had the higher ecological risk indices due to their high toxicity response factors. $R I$ for all sampling sites was below 150, suggesting that the sediments in the river posed a low risk. The $R I$ has been proven as a highly effective tool to assess the overall contamination of sediments of an aquatic ecosystem [34]. However, the unavailability of updated reference metal levels for any selected ecosystem or geographical region could lead to an overestimation or underestimation of the actual pollution load in the sediments and thus the ecological risk index [52]. Therefore, for accurate estimation of ecological risk of trace metals, regular updates for reference level after a certain period of time is required, especially in geological regions with sensitive ecological habitats.

\section{Multivariate Analysis Results}

\section{Correlation Analysis}

Pearson's correlation was performed to analyze the interrelationship between heavy metals in the sediments. The results of the analysis are shown in Table 9. Pearson's correlation matrix showed that there was negative correlation between $\mathrm{Mn}$ and $\mathrm{Zn}$ $(r=-0.716 ; p<0.01)$. While a strong positive correlation was found between $\mathrm{Cu}$ and $\mathrm{Cr}(r=0.601 ; p<0.05)$, Ni and $\mathrm{Cr}(r=0.653 ; p<0.05)$, Ni and $\mathrm{Cu}(r=0.735 ; p<0.01)$, and $\mathrm{Fe}$ and $\mathrm{Cu}(r=0.752 ; p<0.01)$. In contrast, $\mathrm{Co}$ demonstrated no correlation with the other heavy metals. The strong positive correlation between these heavy metals indicates common pollutant sources [11, 13, 47] or similarity in geochemical behaviour [17].

Table 8. The potential ecological risk indices (RI) of heavy metals in surface sediments in all sampling stations in Mangonbangon River.

\begin{tabular}{|c|c|c|c|c|c|c|c|}
\hline \multirow{2}{*}{ Sampling Site } & \multicolumn{6}{|c|}{$E i$} & \multirow{2}{*}{$R I$} \\
\hline & $\mathrm{Zn}$ & $\mathrm{Cr}$ & $\mathrm{Cu}$ & $\mathrm{Ni}$ & Mn & $\mathrm{Co}$ & \\
\hline US01 & 0.81 & 1.92 & 9.30 & 2.75 & 0.42 & 3.55 & 18.75 \\
\hline US02 & 1.88 & 0.72 & 3.25 & 0.90 & 0.37 & 4.20 & 11.32 \\
\hline US03 & 1.89 & 2.92 & 16.30 & 4.60 & 0.48 & 2.15 & 28.34 \\
\hline MS04 & 2.03 & 2.84 & 19.20 & 4.65 & 0.32 & 3.15 & 32.19 \\
\hline MS05 & 2.78 & 1.96 & 11.30 & 4.90 & 0.28 & 1.45 & 22.67 \\
\hline MS06 & 2.11 & 1.50 & 12.55 & 4.15 & 0.31 & 6.10 & 26.72 \\
\hline MS07 & 2.30 & 1.64 & 13.90 & 3.90 & 0.38 & 5.20 & 27.32 \\
\hline MS08 & 2.47 & 2.12 & 11.15 & 4.75 & 0.32 & 5.00 & 25.81 \\
\hline DS09 & 2.51 & 2.82 & 13.95 & 7.15 & 0.22 & 4.50 & 31.15 \\
\hline DS10 & 2.53 & 2.68 & 12.20 & 5.85 & 0.26 & 5.10 & 28.62 \\
\hline DS11 & 2.58 & 2.46 & 24.10 & 7.20 & 0.23 & 6.65 & 43.22 \\
\hline DS12 & 2.48 & 1.04 & 11.35 & 4.90 & 0.22 & 2.80 & 22.79 \\
\hline DS13 & 2.59 & 1.22 & 13.70 & 3.80 & 0.20 & 1.05 & 22.56 \\
\hline DS14 & 2.55 & 1.98 & 8.70 & 3.40 & 0.30 & 5.50 & 22.43 \\
\hline Minimum & 0.81 & 0.72 & 3.25 & 0.90 & 0.20 & 1.05 & 11.32 \\
\hline Maximum & 2.78 & 2.92 & 24.10 & 7.20 & 0.48 & 6.65 & 43.22 \\
\hline Mean & 2.25 & 1.99 & 12.93 & 4.49 & 0.31 & 4.03 & 25.99 \\
\hline
\end{tabular}


Table 9. Pearson's correlation coefficient of heavy metal concentrations of sediments in Mangonbangon River.

\begin{tabular}{|c|c|c|c|c|c|c|c|}
\hline Metal & $\mathrm{Zn}$ & $\mathrm{Cr}$ & $\mathrm{Cu}$ & $\mathrm{Ni}$ & $\mathrm{Mn}$ & $\mathrm{Co}$ & $\mathrm{Fe}$ \\
\hline $\mathrm{Zn}$ & 1 & & & & & & \\
\hline $\mathrm{Cr}$ & 0.033 & 1 & & & & & \\
\hline $\mathrm{Cu}$ & 0.232 & $0.601^{*}$ & 1 & & & & \\
\hline $\mathrm{Ni}$ & 0.517 & $0.653^{*}$ & $0.735^{* *}$ & 1 & & & \\
\hline $\mathrm{Mn}$ & $-0.716^{* *}$ & 0.111 & -0.217 & -0.529 & 1 & & \\
\hline $\mathrm{Co}$ & 0.049 & 0.121 & 0.126 & 0.206 & -0.053 & 1 & \\
\hline $\mathrm{Fe}$ & -0.127 & 0.452 & $0.752^{* *}$ & 0.455 & 0.071 & -0.143 & 1 \\
\hline
\end{tabular}

${ }^{*} p<0.05 ; * * p<0.01$

\section{Cluster Analysis}

Hierarchical agglomerative cluster analysis was performed using the nearest neighbour method and Pearson correlation as a measure of similarity to determine the source apportionment of heavy metals in the sediments. The heavy metals were grouped into four clusters as depicted in the dendrogram (Fig. 2). Cluster 1 comprised $\mathrm{Cu}, \mathrm{Fe}, \mathrm{Ni}$, and $\mathrm{Cr}$, reflecting their common origin, which could be associated with anthropogenic activities. Cluster 2 comprised $\mathrm{Zn}$, which also showed the interrelationship with $\mathrm{Cr}$ and $\mathrm{Co}$. In addition, cluster 3 comprised Co. Cluster 4 was found to be comprised by $\mathrm{Mn}$, suggesting that it was not related to the remaining heavy metals. It also indicated a different origin or geochemical behaviour.

\section{Principal Component Analysis}

Principal component analysis (PCA) was performed to further determine the source apportionment of heavy metals in the sediments and also in support of CA. The relationships between heavy metals with respect to the three principal components are plotted in the rotated space (Figure 3). The PCA extracted three principal components with eingenvalues explaining $84.984 \%$ of the total variance. The results of the PCA corroborated with the results of CA with first principal component that accounted for $39.346 \%$ of the total variance with high positive loadings for $\mathrm{Cr}(0.810), \mathrm{Cu}(0.902), \mathrm{Ni}$ (0.747), and $\mathrm{Fe}(0.850)$. The combinations of these heavy metals in the first component suggested anthropogenic sources, since $\mathrm{Cr}$ in this component had values showing enrichment in sediments as well as $\mathrm{Cr}$ and $\mathrm{Ni}$ to a lesser extent. The second component accounted for $29.869 \%$ of the total variance with high positive and negative loading for Zn (0.914) and Mn (-0.913), respectively. The inverse relationship of $\mathrm{Mn}$ with $\mathrm{Zn}$ was an indication of external inputs of the heavy metal [53], in this case $\mathrm{Zn}$, which could be associated with anthropogenic sources. The third principal component accounted for
$15.769 \%$ of the total variance with high positive loading for Co (0.964). This component suggested that the metal is derived from natural sources such as from the weathering of parent rocks and minerals. PCA results showing small (positive or negative) loadings indicating weak relationships, while large (absolute) loadings indicated strong relationships between heavy metals [37].

\section{Conclusions}

An investigation of heavy metal $(\mathrm{Zn}, \mathrm{Cr}, \mathrm{Cu}, \mathrm{Ni}$, $\mathrm{Mn}, \mathrm{Co}$, and $\mathrm{Fe}$ ) contamination in surface sediments was carried out in the Mangonbangon River, northestern Leyte, the Philippines. The concentration of heavy metals in sediments decreased in the following order: $\mathrm{Fe}>\mathrm{Mn}>\mathrm{Zn}>\mathrm{Cu}>\mathrm{Cr}>\mathrm{Ni}>\mathrm{Co}$. Analysis of the $\mathrm{EF}, \mathrm{CF}$, and $I_{\text {geo }}$ of heavy metals showed that surface sediments were polluted with $\mathrm{Zn}$ and $\mathrm{Cu}$, while the others $(\mathrm{Cr}, \mathrm{Ni}, \mathrm{Mn}, \mathrm{Co}$, and $\mathrm{Fe})$ indicated background concentration to minor contamination. For overall pollution, PLI showed that much of the sampling sites in the Mangonbangon River were generally unpolluted with the studied heavy metals. In order to assess the ecological risk of heavy metal contamination in surface sediments, SQGs and RI were applied. The results showed that $\mathrm{Zn}, \mathrm{Cr}, \mathrm{Cu}$, and $\mathrm{Ni}$ were likely to result in a deleterious effect on bottom-dwelling organisms. RI values for all sampling sites indicated low ecological risk in the sediments. In this study, multivariate analyses including correlation analysis, CA, and PCA were performed as to determine the source apportionment of heavy metals in the sediments. Correlation analysis between heavy metals indicated common pollution sources or identical geochemical behavior for $\mathrm{Cu}$, $\mathrm{Cr}, \mathrm{Ni}$, and $\mathrm{Fe}$. The $\mathrm{CA}$ and PCA clearly showed that these heavy metals $(\mathrm{Cu}, \mathrm{Cr}, \mathrm{Ni}$, and $\mathrm{Fe})$ were in the same cluster and component, thus suggesting strong relationships, and their combination indicated anthropogenic sources of these heavy metals. 


\section{Acknowledgements}

We are grateful to the Research Unit of Visayas State University-Alangalang for financial support for this study.

\section{References}

1. PENG J.-F., SONG Y.-H., YUAN P., CUI X.-Y., QIU G.-L. The remediation of heavy metals contaminated sediment. J. Hazard. Mater. 161, 633, 2009.

2. KUNCHEVA L.I., WRENCH J., JAIN L.C., AL-ZAIDAN A.S. A fuzzy model of heavy metal loadings in Liverpool bay. Environ. Modell. Softw. 15, 161, 2000.

3. VRHOVNIK P., ARREBOLA J.P., SERAFIMOVSKI T., DOLENEC T., ŠMUC N.R., DOLENEC M., MUTCH E. Potentially toxic contamination of sediments, water and two animal species in Lake Kalimanci, FYR Macedonia: Relevance to human health. Environ. Pollut. 180, 92, 2013.

4. WEI B., YANG L. A review of heavy metal contaminations in urban soils, urban road dusts and agricultural soils from China. Microchem. J. 94, 99, 2010.

5. MOHIUDDIN K.M., OGAWA Y., ZAKIR H.M., OTOMO K., SHIKAZONO N. Heavy metals contamination in water and sediments of an urban river in a developing country. Int. J. Environ. Sci. Tech. 8 (4), 723, 2011.

6. ADAMU C.I., NGANJE T.N., EDET A. Heavy metal contamination and health risk assessment associated with abandoned barite mines in Cross River State, southeastern Nigeria. Environ. Nanotechnol. Monit. Manag. 3, 10, 2015.

7. SKORDAS K., KELEPERTZIS E., KOSMIDIS D., PANAGIOTAKI P., VAFIDIS D. Assessment of nutrients and heavy metals in the surface sediments of the artificially lake water reservoir Karla, Thessaly, Greece. Environ. Earth. Sci. 73, 4483, 2015.

8. PURUSHOTHAMAN P., CHAKRAPANI G.J. Heavy metals fractionation in Ganga River sediments, India. Environ. Monit. Assess. 132, 475, 2007.

9. MILENKOVIC N., DAMJANOVIC M., RISTIC M. Study of heavy metal pollution in sediments from the Iron Gate (Danube River), Serbia and Montenegro. Pol. J. Environ. Stud. 14 (6), 781, 2005.

10. TANG W., SHAN B., ZHANG W., ZHANG H., WANG L., DING Y. Heavy metal pollution characteristics of surface sediments in different aquatic ecosystems in eastern China: A comprehensive understanding. PLoS ONE. 9, 9, 2014.

11. ZAREI I., POURKHABBAZ A., KHUZESTANI R.B. An assessment of metal contamination risk in sediments of Hara Biosphere Reserve, southern Iran with a focus on application of pollution indicators. Environ. Monit. Assess. 186, 6047, 2014.

12. ZHANG C., QIAO Q., PIPER J.D.A., HUANG B. Assessment of heavy metal pollution from a Fe-smelting plant in urban river sediments using environmental magnetic and geochemical methods. Environ. Pollut. 159, 3057, 2011.

13. YANG Y., CHEN F., ZHANG L., LIU J., WU S., KANG M. Comprehensive assessment of heavy metal contamination in sediment of the Pearl River Estuary and adjacent shelf. Mar. Pollut. Bull. 64, 1947, 2012.

14. BASTAMI K.D., BAGHERI H., KHEIRABADI V., ZAFERANI G.G., TEYMORI M.B., HAMZEHPOOR A., SOLTANI F., HAGHPARAST S., HARAMI S.R.M.,
GHORGHANI N.F., GANJI S. Distribution and ecological risk assessment of heavy metals in surface sediments along southeast coast of the Caspian Sea. Mar. Pollut. Bull. 81, 262,2014

15. ADEKOLA F.A., ELETTA O.A.A. A study of heavy metal pollution of Asa River, Ilorin. Nigeria; trace metal monitoring and geochemistry. Environ. Monit. Assess. 125, 157, 2007.

16. ALI M.M., ALI M.L., ISLAM M.S., RAHMAN M.Z. Preliminary assessment of heavy metals in water and sediment of Karnaphuli River, Bangladesh. Environ. Nanotechnol. Monit. Manag. 5, 27, 2016.

17. PANDEY J., SINGH R. Heavy metals in sediments of Ganga River: up- and downstream urban influences. Appl. Water. Sci. 1, 2015.

18. QUIÑONES C.M.O., ASIO V.B. Soils derived from ophiolitic rocks in northeastern Leyte: Morphological, physical, and chemical properties. Annals of Tropical Research. 37 (2), 36, 2015.

19. SUERTE L.O., YUMUL G.P.,JR., TAMAYO R.A.,JR., DIMALANTA C.B., ZHOU M.-F., MAURY R.C., POLVÉ M., BALCE C.L. Geology, geochemistry and U-Pb SHRIMP age of the Tacloban Ophiolite Complex, Leyte Island (Central Philippines): Implications for the existence and extent of the Proto-Philippine Sea Plate. Resour. Geol. 55 (3), 207, 2005.

20. HU Y., LIU X., BAI J., SHIH K., ZENG E.Y., CHENG H. Assessing heavy metal pollution in the surface soils of a region that had undergone three decades of intense industrialization and urbanization. Environ. Sci. Pollut. Res. 20, 6150, 2013.

21. TUREKIAN K.K., WEDEPOHL K.H. Distribution of the elements in some major units of the earth's crust. Geol. Soc. Am. Bull. 72, 175, 1961.

22. LOSKA K., WIECHUŁA D., BARSKA B., CEBULA E., CHOJNECKA A. Assessment of arsenic enrichment of cultivated soils in southern Poland. Pol. J. Environ. Stud. 12 (2), 187, 2003

23. LOSKA K., WIECHUŁA D., KORUS I. Metal contamination of farming soils affected by industry. Environ. Int. 30, 159, 2004.

24. SEKABIRA K., ORYEM ORIGA H., BASAMBA T.A., MUTUMBA G., KAKUDIDI E. Assessment of heavy metal pollution in the urban stream sediments and its tributaries. Int. J. Environ. Sci. Tech. 7 (3), 435, 2010.

25. ÖZKAN E.Y. A new assessment of heavy metal contaminations in an eutrophicated bay (Inner Izmir Bay, Turkey). Turk. J. Fish. Aquat. Sc. 12, 135, 2012.

26. SAKAN S.M., ĐORDEVIĆ D.S., MANOJLOVIĆ D.D., PREDRAG P.S. Assessment of heavy metal pollutants accumulation in the Tisza river sediments. J. Environ. Manage. 90, 3382, 2009.

27. KADHUM S.A., ISHAK M.Y., ZULKIFLI S.Z. Evaluation and assessment of baseline metal contamination in surface sediments from the Bernam River, Malaysia. Environ. Sci. Pollut. Res. 23 (7), 6312, 2015.

28. HÅKANSON L. An ecological risk index for aquatic pollution control. A sedimentological approach. Water Res. 14, 975, 1980 .

29. MULLER G. Index of geo-accumulation in sediments of the Rhine River. Geol. J. 2 (3), 108, 1969

30. VAROL M., ŞEN B. Assessment of nutrient and heavy metal contamination in surface water and sediments of the upper Tigris River, Turkey. Catena. 92, 1, 2012.

31. TOMLINSON D.L., WILSON J.G., HHARRIS C.R., JEFFREY D.W. Problems in the assessment of heavy-metal 
levels in estuaries and the formation of a pollution index. Helgol. Wiss. Meeresunlter. 33 (1-4), 566, 1980.

32. WANG J., LIU G., LU L., LIU H. Metal distribution and bioavailability in surface sediments from the Huaihe River, Anhui, China. Environ. Monit. Assess. 188 (3), 1, 2016.

33. FU J., ZHAO C., LUO Y., LIU C., KYZAS G.Z., LUO Y., ZHAO D., AN S., ZHU H. Heavy metals in surface sediments of the Jialu River, China: Their relations to environmental factors. J. Hazard. Mater. 270, 102, 2014.

34. LIN C., HE M., LIU X., GUO W., LIU S. Contamination and ecological risk assessment of toxic trace elements in the Xi River, an urban river of Shenyang city, China. Environ. Monit. Assess. 185, 4321, 2013.

35. MACDONALD D.D., INGERSOLL C.G., BERGER T.A. Development and evaluation of consensus-based sediment quality guidelines for freshwater ecosystems. Arch. Environ. Contam. Toxicol. 39, 20, 2000.

36. LI X., LIU L., WANG Y., LUO G., CHEN X., YANG X., GAO B., HE X. Integrated assessment of heavy metal contamination in sediments from a coastal industrial basin, NE China. PLoS ONE. 7, 6, 2012.

37. ATTIA O.E.A., GHREFAT H. Assessing heavy metal pollution in the recent bottom sediments of Mabahiss Bay, North Hurghada, Red Sea, Egypt. Environ. Monit. Assess. 185 (12), 9925, 2013.

38. RA K., KIM E.-S., KIM K.-T., KIM J.-K., LEE J.-M., CHOI J.-Y. Assessment of heavy metal contamination and its ecological risk in the surface sediments along the coast of Korea. J. Coastal Res. 1 (65), 105, 2013.

39. REN J., SHANG Z., TAO L., WANG X. Multivariate analysis and heavy metals pollution evaluation in Yellow River surface sediments. Pol. J. Environ. Stud. 24 (3), 1041, 2015.

40. MOHIUDDIN K.M., OTOMO K., OGAWA Y., SHIKAZONO N. Seasonal and spatial distribution of trace elements in the water and sediments of the Tsurumi River in Japan. Environ. Monit. Assess. 184, 265, 2012.

41. MORILLO J., USERO J., GRACIA I. Heavy metal distribution in marine sediments from the southwest coast of Spain. Chemosphere. 55, 431, 2004.

42. O'SULLIVAN A., WICKE D., COCHRANE T. Heavy metal contamination in an urban stream fed by contaminated air-conditioning and stormwater discharges. Environ. Sci. Pollut. Res. 19 (3), 903, 2012.

43. MITO S., SOHRIN Y., NORISUYE K., MATSUI M., HASEGAWA H., MARUO M., TSUCHIYA M.,
KAWASHIMA M. The budget of dissolved trace metals in Lake Biwa, Japan. Limnology. 5, 7, 2004.

44. SEKABIRA K., ORYEM ORIGA H., BASAMBA T.A., MUTUMBA G., KAKUDIDI E. Heavy metal assessment and water quality values in urban stream and rain water. Int. J. Environ. Sci. Tech. 7 (4), 759, 2010.

45. PRADIT S., WATTAYAKORN G., ANGSUPANICH S., BAEYENS W., LEERMAKERS M. Distribution of trace elements in sediments and biota of Songkhla Lake, southern Thailand. Water Air Soil Pollut. 206 (1), 155, 2010.

46. LOSKA K., WIECHUŁA D. Application of principal component analysis for the estimation of source of heavy metal contamination in surface sediments from the Rybnik Reservoir. Chemosphere. 51, 723, 2003.

47. GUPTA S.K., CHABUKDHARA M., KUMAR P., SINGH J., BUX F. Evaluation of ecological risk of metal contamination in river Gomti, India: A biomonitoring approach. Ecotoxicol. Environ. Saf. 110, 49, 2014.

48. ISLAM M.S., AHMED M.K., RAKNUZZAMAN M., HABIBULLAH -AL- MAMUN M., ISLAM M.K. Heavy metal pollution in surface water and sediment: A preliminary assessment of an urban river in a developing country. Ecol. Indic. 48, 282, 2015.

49. KADHUM S.A., ISHAK M.Y., ZULKIFLI S.Z., HASHIM R.B. Evaluation of the status and distributions of heavy metal pollution in surface sediments of the Langat River Basin in Selangor Malaysia. Mar. Pollut. Bull. 101, 391, 2015.

50. KARBASSI A.R., MONAVARI S.M., NABI BIDHENDI GH.R., NOURI J., NEMATPOUR K. Metal pollution assessment of sediment and water in the Shur River. Environ. Monit. Assess. 147 (1-3), 107, 2008.

51. KWON Y.T., LEE C.W., AHN B.Y. Sedimentation pattern and sediments bioavailability in a wastewater discharging area by sequential metal analysis. Microchem. J. 68, 135, 2001.

52. PROTANO C., ZINNÀ L., GIAMPAOLI S., SPICA V.R., CHIAVARINI S., VITALI M. Heavy metal pollution and potential ecological risks in rivers: a case study from Southern Italy. Bull. Environ. Contam. Toxicol. 92, 75, 2014.

53. LI S., ZHANG Q. Spatial characterization of dissolved trace elements and heavy metals in the upper Han River (China) using multivariate statistical techniques. J. Hazard. Mater. 176, 579, 2010. 
